UDC: 81'373.23:821.14’02 Trasimed

Мирко Обрадовић

Универзитет у Београду

Филозофски факултет

Одељење за историју

mdobrado@f.bg.ac.rs
Оригинални научни рад

примљено: 7. мај 2013

прихваћено: 1. октобар 2013

\title{
ПРИЛОЗИ ПРОУЧАВАЊУ НЕЛЕИДСКЕ АНТРОПОНИМИЈЕ II - ХЕРОЈСКО ИМЕ ТРАСИМЕД КАО ЛИЧНО ИМЕ КОД ХЕЛЕНА
}

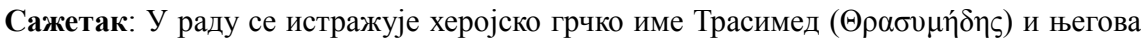
дистрибуција као личног имена у хеленском свету. На богатом антропонимијском материјалу из различитих делова грчког света анализирају се могући разлози за давање овог херојског имена смртним људима. Име Трасимед је као нелеидско (име једног од Несторових синова) било прихватљиво нарочито Јоњанима, одакле се може тумачити и његова популарност у Атици, али и у другим јонским крајевима: на острвима у Егејском мору и у малоазијској Јонији. Херојско име Трасимед је, дакле, као лично име могло да буде давано потомству са јасном свешћу да је херојско и нелеидско, али се његова популарност у Атини, одакле долази далеко највише потврда у класичном периоду (V-IV век пре н. е.), може најпре објаснити самим његовим значењем и очекивањима од носиоца имена, јер се као и остала именска образовања изведена од придева $९ \alpha \sigma u ́ \varsigma$ (у значењу „храбар, одважан, дрзак, неустрашив“) односи на особине које треба да красе успешног ратника и државника. Управо имена типа $\Theta \rho \alpha \sigma v-$ као да веома добро одговарају атинском духу класичне епохе, јер одражавају оне особине грађана које су у демократском друштву биле нарочито на цени - одлучно и енергично поступање и спремност на жртву за опште добро. С друге стране, изузимајући Атику, херојско име Трасимед је као лично име највише заступљено у антропонимији острва Родоса. То не треба да чуди, јер је реч о имену које има панхеленски карактер, а Родос је као богати трговачки полис, нарочито у хеленистичком периоду, одржавао живе економске и политичке везе са готово свим хеленским и хеленизованим заједницама на широком простору Медитерана. Разлози за популарност имена можда стоје у вези и са „проналажењем сродства“

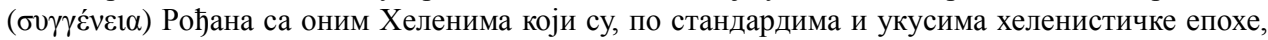
могли бити сматрани Нелејевим и Несторовим потомцима, а то су у периоду од IV века пре н. е. били, пре свих, Месењани. Овим претпостављеним историјским и псеудоисторијским везама између Рођана и Месењана би се најпре могле објаснити честе потврде имена Трасимед, па и других нелеидских имена (Нестор, Антилох, Пејсистрат) као личних имена на острву Родосу, посебно у хеленистичком периоду.

Кључне речи: Трасимед, грчка антропонимија, Нелеиди, етимологија, грчка епика, мит, историја, политика, културне вредности.

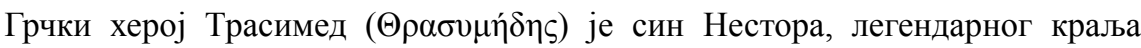
Пила и једног од великих хероја грчке епике. Уз брата Антилоха, он је свакако и најважнији од Несторових директних потомака забележених у старој хеленској 
традицији. Као и херој Антилох, и Трасимед је био учесник тројанског похода, а познија традиција га ставља и на списак оних Ахајаца који су се налазили сакривени у дрвеном коњу и били коначни освајачи Троје. ${ }^{1}$ Иако се није под Тројом нарочито истакао, ${ }^{2}$ песник Илијаде и за Трасимеда, као и за најважније ахајске вође, користи

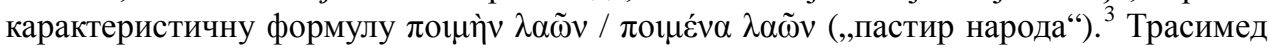
је уједно и један од ретких грчких хероја који је успешно, заједно са оцем Нестором, преживео све тегобе рата и повратка кући након пада Троје. У другом великом хомерском епу Одисеји управо је он тај који, заједно са братом Пејсистратом и оцем Нестором, дочекује Одисејевог сина Телемаха у Пилу. ${ }^{4}$ Сада као најстарији од преосталих Несторових синова, приликом приношења жртве, он је представљен

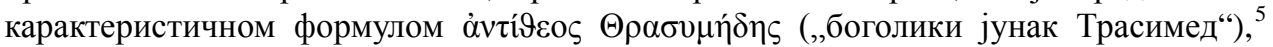
али исто тако и као $\mu \varepsilon v \varepsilon \pi \tau o ́ \lambda \varepsilon \mu о \varsigma \Theta \rho \alpha \sigma v \mu \eta \dot{\delta} \delta\rceil \varsigma$ (,,у боју устрајни јунак Трасимед“) и

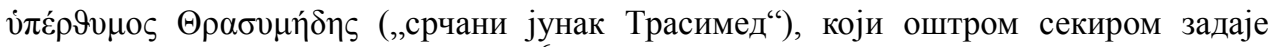
смртни ударац жртвеном говечету. ${ }^{6}$ Попут оца Нестора, и Трасимед је изгледа у традицији доживео крепку и срећну старост, а његов гроб је још у римско доба показиван у близини Пила. ${ }^{7}$

Према грчком миту, Трасимедови потомци нису били те среће, већ су у време тзв. повратка Хераклида на Пелопонез морали да напусте Пил и Месенију. Као и остали Нелеиди, уточиште су нашли, по традицији, у Атици. Ово широко распрострањено веровање, као и чињеница да су Нелеиди својим врлинама и храброшћу досегли чак и краљевски положај у Атини, морало је оставити трага у

\footnotetext{
${ }^{1}$ Qu. Smyrn. Posth. XII 319. Као и његов брат Антилох, и Трасимед је у боју убио двојицу Тројанаца, упор. Hygin. Fab. 114. Уопште о Трасимеду, Несторовом сину, у грчком миту, традицији и уметности, упор. Ruhl, Roscher V, 1916-1924, 865-66, s.v. Thrasymedes (1); Bernert, RE VI A 1, 1936, 593-594, s.v. Thrasymedes (1).

2 Трасимед није припадао кругу највећих хероја, али већ Хомер у Илијади бележи неке његове јуначке подвиге: у боју је тако одлучно притекао у помоћ брату Антилоху када је на овога копљем насрнуо Ликијац Марис (Il. XVI 321-325); Трасимед је и тај који оцу Нестору позајмљује свој штит, а сам носи очев (Il. XIV 10-11), што је свакако мотив који наговештава један од судбоносних догађаја читавог епа у коме Патрокло позајмљује Ахилејеву ратну опрему. Упор. R. Janko, The Iliad. A Commentary, Vol. IV, Books 13-16, Cambridge 1994, 152, 359. Трасимед на другом месту, такође, великом хероју Диомеду уступа свој штит и мач када овај заједно са Одисејем креће у тројански табор (Il. X 255-256).

${ }^{3}$ Il. IX 81. За метафоричку употребу израза „пастир народа“ у епској поезији, упор. J. Haubold, Homer's People: Epic Poetry and Social Formation, Cambridge 2000, 17-36. Да је то концепт (у основи одређен изреком „народ без краља као овце без пастира“) који порекло води са Блиског истока и може се пратити још од старих цивилизација Месопотамије, упор. М. L. West, The East Face of Helicon. West Asiatic Elements in Greek Poetry and Myth, Oxford 1997, 226-227.

${ }^{4}$ Od. III 39.

${ }^{5}$ Od. III 414.

${ }^{6}$ Od. III 442-450.

${ }^{7}$ Упор. Paus. IV 36, 2. Обично се сматра да је то микенска гробница чији се остаци налазе у Воидокилији у Месенији (у близини тзв. Несторове пећине) са бројним траговима који сежу у прошлост све до неолита, а код које је у хеленистичком периоду практикован култ хероја. Упор. S. E. Alcock, Tomb Cult and Post-Classical Polis, American Journal of Archaeology 95, Boston 1991, 461; N. Luraghi, The Ancient Messenians: Constructions of Ethnicity and Memory, Cambridge 2008, 244. Паусанија (IV 31, 11) бележи и да је Трасимед заједно са оцем Нестором и братом Антилохом представљен као владар на једној слици на зиду храма подигнутом у Месенији који је осликао сликар Омфалион.
} 
херојским генеалогијама и породичним традицијама каснијих историјских епоха. Из тог разлога су не само породица последњих атичких краљева, односно првих

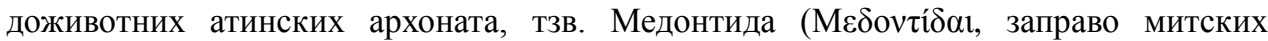

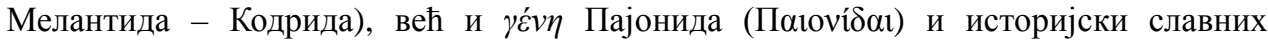

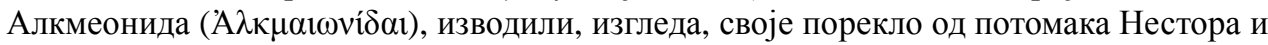
Периклимена, Нелејевих синова, и других избеглица из Пила који су се, по традицији, населили у Атици. ${ }^{8}$ Исто као и остали Несторови синови (Антилох, Пејсистрат), и Трасимед је као херој био привлачан за потоње генерације, па су га аристократи у грчким градовима, а нарочито атински, следећи херојске генеалогије, могли узети за свог претка, и на тај начин се преко њега повезати са светом богова и хероја. Тако су, следећи уобичајену праксу повезивања херојског племства и херојских генеалогија са породичном традицијом, Алкмеониди (А $А \kappa \mu \alpha \imath \omega v i ́ \delta \alpha \imath)$, једна од водећих аристократских атинских породица архајске епохе, изводили своје

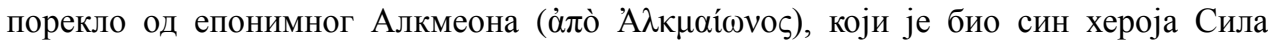

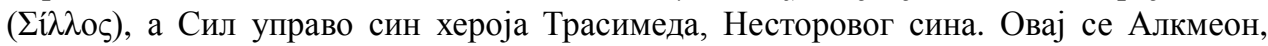
према традицији, након повратка Хераклида на Пелопонез, заједно са осталим Нелеидима избеглим из Пила, населио у Атици. Своје нелеидско порекло могли су Алкмеониди користити као предност и капитал у политичкој борби која се разбуктала у атинском полису архајске епохе (VII-VI век пре н. е.). ${ }^{9}$

Из горе наведених разлога, као и због свеопште популарности хомерске епике, није необично да се име Трасимед јави и као лично име смртних људи у различитим периодима грчке историје. По својој етимологији и значењу, херојско

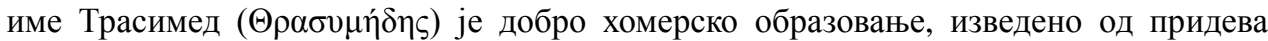

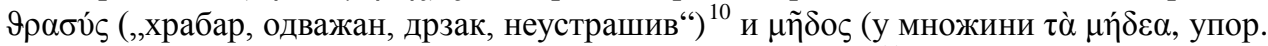

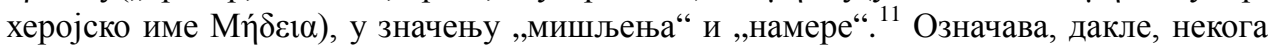

\footnotetext{
${ }^{8}$ Ова је традиција од сачуваних извора најпотпуније забележена код периегета Паусаније у његовом Опису Хеладе (II 18, 8), одакле произлази да су Мелантиди представљали Периклименово потомство, да Алкмеониди воде порекло од Несторовог сина Трасимеда, док Пајониди потичу од Антилоховог сина

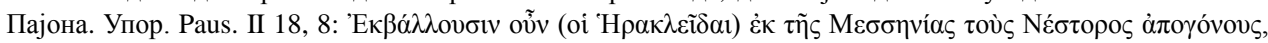

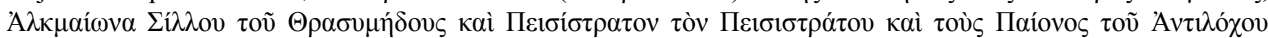

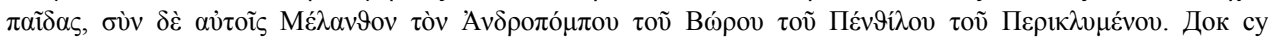
Алкмеониди историјски добро потврђени, о роду Пајонида не знамо много, а постојање истоимене атичке

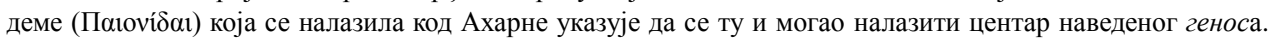
Упор. R. Parker, Athenian Religion: A History, Oxford 1996, 326.

${ }^{9}$ О Алкмеонидима и њиховој породичној традицији, упор. J. Toepffer, Attische Genealogie, Berlin 1889, 225-227; J. Toepffer, RE I, 1894, 1556-57, s.v. Alkmaionidai; H. T. Wade-Gery, Eupatridai, Archons, and Areopagus II, Classical Quarterly 25, London 1931, 82-83; C. W. Eliot, Where did the Alkmaionidai Live?, Historia 16, Wiesbaden 1967, 279-286; J. K. Davies, Athenian Propertied Families 600-300 B.C., Oxford 1971, 368-370; R. Thomas, Oral Tradition and Written Record in Classical Athens, Cambridge 1989, 144-154.

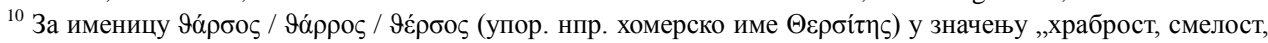

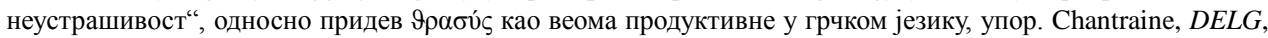
423-424, s.v. Эápбos.

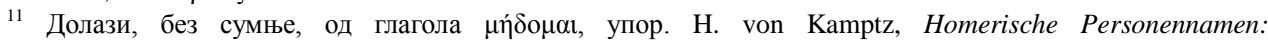
sprachwissenschaftliche und historische Klassifikation, Göttingen 1982, 89, 199. За честа, не само хомерска, образовања личних имена на - $\dot{\eta}_{\delta} \eta \varsigma$, упор. такође A. Fick, Die griechischen Personennamen nach ihrer Bildung erklärt und systematisch geordnet (bearbeitet von F. Bechtel und A. Fick), Göttingen 1894², 206; F.
} 
ко „брзо и одлучно мисли“, али, пренесено, и некога ко „одлучно дела“, односно онога ко је, пре свега, активан и предузимљив. Имена овог типа односе се, дакле, на добре и очекиване особине које треба да красе успешног државника и ратника. Име je, током дуге хеленске историје, могло, као хомерско и херојско, да буде схваћено као аристократско, племићко, и да буде давано потомству са јасном свешћу да је херојско и нелеидско. Међутим, овај антропоним, као, вероватно, и остала лична

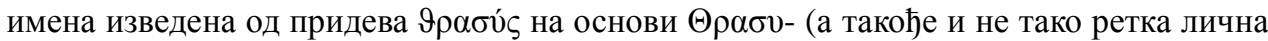
имена образована на основама $\Theta \alpha \rho \sigma v-$ и $\Theta \alpha \rho \rho v-),{ }^{12}$ могла су у демократском друштву да буду најпре повезивана са енергичношћу и предузимљивошћу грађана. Одатле су и честа лична имена овог типа, од којих су нека по пореклу извесно хомерска и епска, а друга опет веома фреквентна у класичној и хеленистичкој епоси

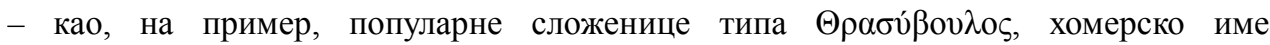
$\Theta \rho \alpha \sigma v ́ \delta \eta \mu о \varsigma$, затим веома често име $\Theta \rho \alpha \sigma v \kappa \lambda \tilde{\eta} \varsigma$, такође чест хипокористик

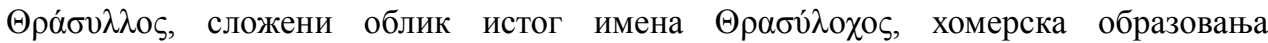

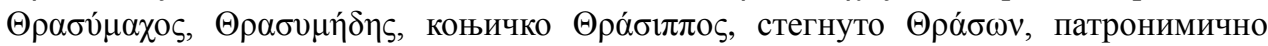
$\Theta \rho \alpha \sigma \omega v i \delta$ п и друга. Ова имена посебно су честа у Атини класичне епохе (V и IV век пре н. е.), што се лако може констатовати већ самим увидом у други том оксфордског Лексикона грчких личних имена (LGPN II) који је у целини посвећен антропонимији Атике. Управо оваква имена као да одговарају атинском духу класичне епохе, јер одражавају особине грађана које су у демократском друштву биле нарочито на цени - одлучно и енергично делање и спремност на жртву за опште добро.

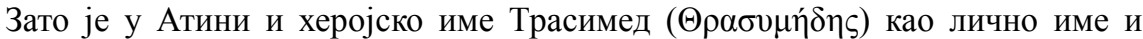
најбоље потврђено, па је чак више од двадесет атинских Трасимеда забележено у

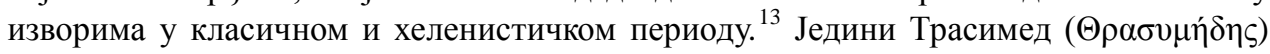

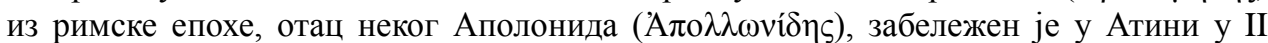
веку наше ере. ${ }^{14}$ Међу атинским Трасимедима има грађана из различитих атинских дема, људи различитих занимања, различитог материјалног статуса. Неке од ових потврда су занимљиве, али тешко је данас рећи да ли је и у којој мери име Трасимед у Атини давано као лично име баш са погледом на хероја Трасимеда, Несторовог сина. Зато име Трасимед у Атини класичне епохе, као што је већ речено, треба гледати у ширем контексту популарних и за демократску Атину очекиваних образовања типа $\Theta \rho \alpha \sigma v-$. На то указују и случајеви где се у оквиру једне породице јављају сродни антропоними, у којима се, кроз генерације, задржава као карактеристични део имена елемент $\Theta \rho \alpha \sigma v-$, као, на пример, Трасон, син Трасимеда

\footnotetext{
Bechtel, Die historischen Personennamen des Griechischen bis zur Keiserzeit, Halle 1917, 313-314. Да су имена овог типа извесно резултат наслеђа микенске епохе, показују и таблице исписане Линеаром Б, које,

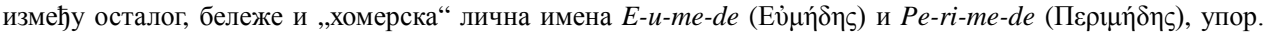
M. Ventris, J. Chadwick, Documents in Mycenaean Greek, Cambridge 1956, 104-105.

${ }^{12}$ Упор. F. Bechtel, Op. cit., 198-199, 211-213.

${ }^{13}$ Упор. LGPN II, s.v. Thrasymedes (2)-(26). Трасимед забележен под редним бројем 26 је метек (странац) који је живео у Атини у првој половини IV века пре н. е.

${ }^{14}$ LGPN II, s.v. Thrasymedes (27). Упор. SEG 29, 152 II, ред 7.
} 


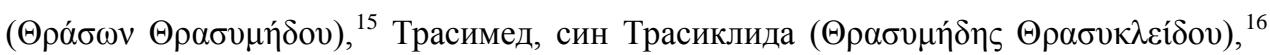

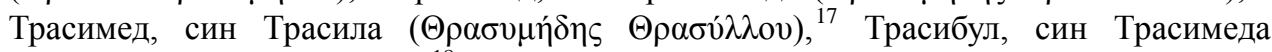
$(\Theta \rho \alpha \sigma u ́ \beta о v \lambda о \varsigma ~ \Theta \rho \alpha \sigma u \mu \eta ́ \delta o v) .{ }^{18}$

Остављајући по страни атинске Трасимеде и сродна антропонимијска образовања из класичне и хеленистичке епохе, изгледа да је херојско име Трасимед као лично име потврђено у Атини још у архајском периоду (VI век пре н. е.). Управо најстарији међу атинским носиоцима овог имена могао би бити извесни Трасимед који се доводи у везу са изградњом Артемидиног храма у Мунихији на једном папирусном фрагменту непознатог грчког путописца. ${ }^{19}$ Исто сматрају приређивачи и издавачи другог тома оксфордског Лексикона грчких личних имена, па је то онда извесно и најранија потврда херојског имена Трасимед као личног имена. ${ }^{20}$ Можемо само претпоставити да је овај Трасимед био племић и да је добио име по хероју Трасимеду, Несторовом сину. Изгледа, међутим, атрактивно да се исти поистовети са

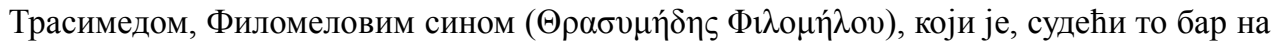
основу једне од прича забележених у Полијеновој збирци ратних лукавстава Cтратегемата ( $\Sigma \tau \rho \alpha \eta \gamma \eta ́ \mu \alpha \alpha)$, био лудо заљубљен у ћерку Пејсистрата, славног атинског тиранина из VI века пре н. е., и чак организовао њену отмицу. Иако на крају ухваћен у покушају бекства и суочен са најтежом казном, Трасимед је својим понашањем и јуначким држањем толико задивио тиранина да му је овај дао руку своје ћерке. ${ }^{21}$ Било би то заиста више од пуке случајности да је тиранин Пејсистрат,

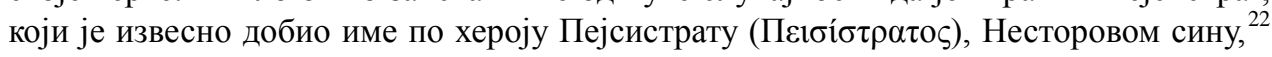
имао зета који је такође носио име по другом Несторовом сину (Трасимеду). Проблем је, међутим, што је ова прича у нешто другачијој обради (заљубљени младић није отмичар, већ само неко ко је дрско у јавности пољубио тиранинову ћерку) позната и другим античким писцима, а Трасимеда као Пејсистратовог зета не спомињу остали сачувани извори. Тако Плутарх у спису који носи назив Изреке краљева и војсковођа (Regum et imperatorum apophthegmata), а који је писац из Херонеје посветио цару Трајану, наводи да се Атињанин заљубљен у тиранинову

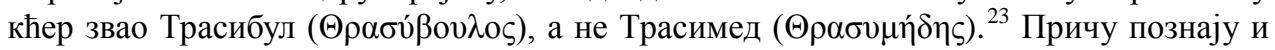
историчар Диодор, као и Валерије Максим, аутор збирке анегдота из времена

\footnotetext{
${ }^{15}$ Agora XV 43, редови 193-194 (већник из деме Анакаје забележен на листи чланова Већа од пет стотина за 335/4. годину пре н. е.). Упор. LGPN II, s.v. Thrasymedes (10).

${ }^{16}$ IG II $^{2} 2385$ II, ред 42 (на списку грађана из филе Кекропиде, средина IV века пре н. е.). Упор. LGPN II, s.v. Thrasymedes (13).

${ }^{17}$ IG II $^{2} 6176$ (Трасимед, син Трасила, из деме Еуонимон, натпис на надгробном споменику са острва Саламине). Упор. LGPN II, s.v. Thrasymedes (14).

${ }^{18}$ Agora XV 61, ред 91 (већник из деме Проспалте на списку чланова Већа од пет стотина за 304/3. годину пре н. е.). Упор. LGPN II, s.v. Thrasymedes (19).

${ }^{19}$ P. Hawara 80, 2 = FGrHist 369 [Anonymer Perieget] F 1.

${ }^{20}$ LGPN II, s.v. Thrasymedes (1).

${ }^{21}$ Polyaen. V 14.

22 О херојском имену Пејсистрат као личном имену намеравам да говорим у следећем наставку ове студије о нелеидским именима.

${ }^{23}$ Plut. mor. 189 C (патронимик није наведен). На исто Плутарх алудира и у спису О контроли гнева (De cohibenda ira). Упор. mor. $457 \mathrm{~F}$.
} 
владавине цара Тиберија, али не наводе име Атињанина који се усудио да салети Пејсистратову кћер. ${ }^{24}$ Проблем изгледа разрешава један фрагмент филозофског дијалога непознатог аутора, пронађен у Оксиринху у Египту. Реч је о измишљеном дијалогу који, између осталог, има за циљ да доведе у непосредну везу законодавца Солона и тиранина Пејсистрата. ${ }^{25}$ Ту се, међутим, наводи да се младић, који је упао у невољу због своје љубави према млађој Пејсистратовој ћерци, звао извесно Трасибул, Филомелов син, а да се његов деда, такође угледни Атињанин, звао Хагнотеј. $^{26}$ Зато, при садашњем стању извора, најбоље је претпоставити да се поменути Атињанин и, како изгледа, Пејсистратов зет, заиста звао Трасибул, а да је реч о грешци код Полијена који доноси име Трасимед. ${ }^{27}$ Треба, међутим, имати у

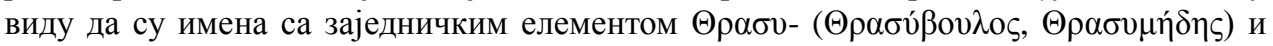
сличним значењем потоњим генерацијама могла звучати слично, па се одатле могу објаснити и грешке код појединих писаца.

Од осталих атинских Трасимеда из класичног и ранохеленистичког периода пажњу привлачи грађанин који је дао свој живот за отаџбину у тешким временима Пелопонеског рата и који је, између осталих, забележен на једном великом списку

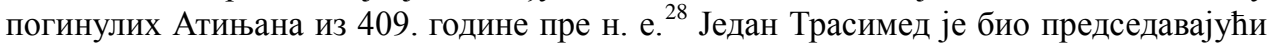
(enucmam) атинског Већа од пет стотина за трајања Коринтског рата (између 394. и 387. године пре н. е.). ${ }^{29}$ С друге стране, Трасимед, Калистратов син из деме Ахарне

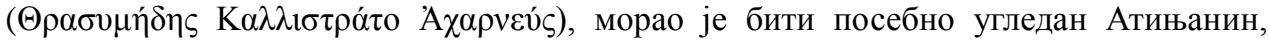
пошто се налазио у штабу познатог атинског стратега Трасибула из деме Колита (вероватно обављао војну службу таксијарха или филарха) и потврђен је на натпису са базе статуе подигнуте $373 / 2$. године пре н. е. у стратегову част. ${ }^{30}$ Лично име Трасимед јавља се и као породично име у породици атинског политичара из средине IV века пре н. е. Диофанта из деме Сфета. Овоме Диофанту, кога помиње Демостен у својим беседама, а који се, између осталог, појављује на натписима и као закупац

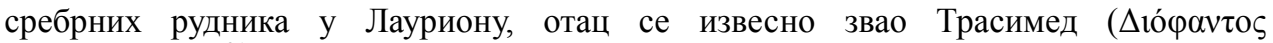
$\Theta \rho \alpha \sigma v \mu \eta ́ \delta o v \varsigma){ }^{31}$ у једној од беседа сачуваних у Демостеновом корпусу (Против Лакрита) наводи се поименце и Диофантов син који се такође звао Трасимед, а истиче се да је реч о познатом грађанину из угледне породице из атичке деме

\footnotetext{
${ }^{24}$ Diod. IX 37, 1 (извор историчар Eфор?); Val. Max. v. 1, ext. 2.

${ }^{25}$ P. Oxy. IV 664, стр. 72-79 (издавачи Grenfell и Hunt настанак дијалога стављају у III, можда чак и у IV век пре н. е.).

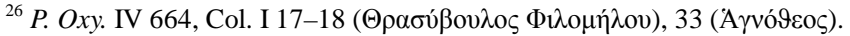

${ }^{27}$ Упор. J. K. Davies, Op. cit., 449.

${ }^{28}$ Agora XVII 23, ред $370=$ IG I ${ }^{3}$ 1191, ред 370. Упор. LGPN II, s.v. Thrasymedes (2).

${ }^{29} I G \mathrm{II}^{2}$ 26, ред 6 (атински почасни декрет за Ифита, Тесалца из града Фарсала). Упор. LGPN II, s.v. Thrasymedes (3).

${ }^{30}$ Упор. Е. Schweigert, Greek Inscriptions (1-13), Hesperia 8, Athens 1939, 3-5, бр. 2.

31 У славној беседи $O$ непоштено извриеном посланству Демостен, између осталог, цитира одлуку Народне скупштине донесену 352. год. пре н. е. на предлог Диофанта (Dem. XIX 86). За натпис који бележи закупце сребрних рудника у Лауриону, упор. Agora XIX P 9, редови 10, 13. Уопште за изворе који сведоче о Диофанту из деме Сфета, упор. LGPN II, s.v. Diophantos (54); за његовог оца Трасимеда, упор. LGPN II, s.v. Thrasymedes (20).
} 
Сфета. ${ }^{32}$ Херојско име Трасимед се у класичној епоси јавља и као лично име на још неколико спискова атинских већника, ${ }^{33}$ али и као име младића на листи атинских ефеба из 332/2. године пре н. е. ${ }^{34}$

Када је реч о другим јонским областима и градовима који су у историјском, политичком и културном погледу били под атинским утицајем, неколико потврда имена Трасимед као личног имена вреди поименце навести. На острву Паросу се тако, на пример, звао и чувени вајар и архитекта, активан у првим деценијама IV века пре н. е. Овај Трасимед, Аригнотов син са Пароса, острва у Кикладима чувеног по најбољем мермеру у целом хеленском свету, славу великог мајстора свог заната стекао је комбинујући различите материјале и технике у изради скулптура. ${ }^{35}$ У томе се очигледно угледао на великог атинског вајара Фидију, а Трасимедово свакако најславније дело била је култна статуа бога Асклепија израђена између, отприлике, 380. и 370. године пре н. е., у хриселефантинској техници за потребе храма у гласовитом Асклепијевом светилишту у Епидауру на Пелопонезу. Дело није сачувано, али путописац Паусанија детаљно описује ову статуу бога Асклепија и

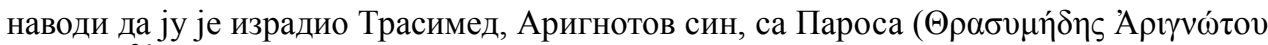

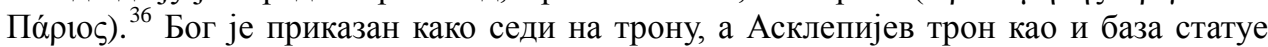
били су богато украшени рељефима. Висина ове култне статуе заједно са базом процењена је у науци између 3 и 6 метара. ${ }^{37}$ Извесно је, међутим, да је Трасимедов Асклепије генерацијама служио као узор и модел каснијим мајсторима који су се угледали на ову скулптуру у изради сопствених представа бога исцелитеља и заштитника лекарске вештине, на сличан начин на који су узор генерацијама уметника биле Фидијине монументалне статуе богиње Атине на атинском Акропољу или статуа бога Зевса из храма у Олимпији. Да је Трасимед радио и декорацију храма и био за Асклепијев храм у Епидауру управо оно што је Фидија био за Партенон на атинском Акропољу, показују документарни извори из Епидаура. Један натпис са базе статуе који бележи посвету Аполону и Асклепију извесног Хармантиде из Епидаура носи Трасимедов потпис као аутора споменика, ${ }^{38}$ а у фрагментарно сачуваним рачунима за изградњу храма забележено је да је Трасимед

\footnotetext{
32 [Dem.] XXXV 6. Упор. LGPN II, s.v. Thrasymedes (21).

${ }^{33}$ Agora XV 34, ред 9 (Дромоклид, син Трасимеда из деме Хагнунта, обављао је службу благајника ( $\tau \alpha \mu i \alpha \varsigma$ ) Већа од пет стотина за 343/2. годину пре н. е.). Упор. LGPN II, s.v. Thrasymedes (15); Agora XV 31, ред 2 (Трасимед, отац већника из деме Ксипете чије име није сачувано на камену на коме су забележени чланови Већа од пет стотина; датовање друга половина IV века пре н. е.). Упор. LGPN II, s.v. Thrasymedes (22); Agora XV 42, ред 142 (Трасимед из деме Пајаније на списку чланова Већа од пет стотина за 336/5. годину пре н. е.). Упор. $L G P N$ II, s.v. Thrasymedes (18).

${ }^{34}$ Reinmuth, Ephebic Inscr. 9 II, ред 34 (ефеб из атичке деме Леуконоје која је припадала фили Леонтиди); за истог Трасимеда, упор. такође $I G$ II $^{2}$ 1554, ред 38 = SEG XVIII 36 A II, ред 219 (дугачка листа манумисија из отприлике 330-320. год. пре н.e.); LGPN II, s.v. Thrasymedes (16).

${ }^{35}$ O Трасимеду Паранину, упор. G. Lippold, $R E$ VI A 1, 1936, 594-595, s.v. Thrasymedes (2); LGPN I, s.v. Thrasymedes (9); A. Stewart, Greek Sculpture: An Exploration, New Haven and London 1990, 273-274; K. D. S. Lapatin, Chryselephantine Statuary in the Ancient Mediterranean World, Oxford 2001, 109-111.

${ }^{36}$ Paus. II 27, 2.

${ }^{37}$ Упор. А. Burford, The Greek Temple Builders at Epidauros, Liverpool 1969, 59; K. D. S. Lapatin, Op. cit., 110.

${ }^{38}{ }^{1 G}$ IV $^{2}$ 1, 198; Упор. LGPN IIIA, s.v. Charmantidas (1).
} 
примио хонорар и за конструкцију врата храма, таванице и других финих унутрашњих радова. ${ }^{39}$ Овај Трасимед Паранин није, међутим, и једини у изворима забележени уметник који је носио име Трасимед. Тако се звао и један мајстор на острву Калимносу у III веку пре н. е. Његов син Никија начинио је, крајем III века пре н. е., лепу посвету богу Аполону. Богу је из захвалности, према обичајима онога времена и из побожности, наменио десетину ( отац произвео, односно прихода добијених од очевих радова. ${ }^{40}$

Када је реч о Кикладима, осим Пароса, и на острву Теносу херојско име Трасимед се као лично име јавља на неколико натписа из прве половине III века пре н. е. Један Трасимед је забележен као предлагач почасног декрета града Теноса за Нимфаја из Бизантиона, ${ }^{41}$ док се извесни Трасимед појављује као продавац дела имовине на дугачком списку с краја IV или с почетка III века пре н. е. ${ }^{42}$ Од градова у малоазијској Јонији, име Трасимед јавља се чак два пута у Колофону на великом натпису на камену с краја IV века пре н. е. који бележи даваоце прилога за изградњу градских бедема. Међу грађанима Колофона забележеним као донаторима, тако читамо имена Трасимеда, сина Хефестионовог, као и још једног грађанина чије име није у потпуности сачувано на камену, а чији се отац извесно звао Трасимед. ${ }^{43}$ Највише, међутим, потврда имена Трасимед као личног имена, бар када је реч о малоазијској Јонији, долази из града Ефеса. Трасимед је и име градског магистрата потврђеног на новцу у првој половини IV века (отприлике између 370. и 360. године пре н. е.), ${ }^{44}$ а ово херојско име забележено је и као име грађана Ефеса на више натписа из класичног и хеленистичког периода ${ }^{45}$ И овде се делом може пратити уобичајена пракса приликом давања имена, добро забележена у Атини, да се у оквиру исте породице јављају сродна имена са карактеристичним елементом $९ \propto \sigma v-$

\footnotetext{
${ }^{39}{ }_{I G} \mathrm{IV}^{2} 1,102$, редови 45-47.

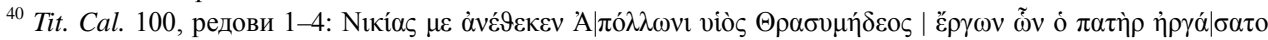

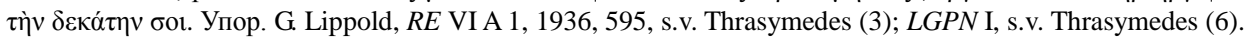

${ }^{41}$ IG XII 5, 802, 2. Упор. LGPN I, s.v. Thrasymedes (26).

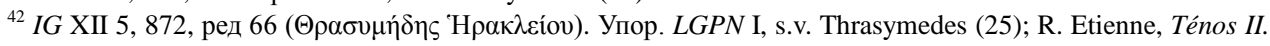
Ténos et les Cyclades du milieu du IV siècle av. J.-C. au III siècle ap. J.-C., Paris 1990, 56.

${ }^{43}$ B. D. Meritt, Inscriptions of Colophon, American Journal of Philology 56, Baltimore 1935, стр. 365 бр. I 427

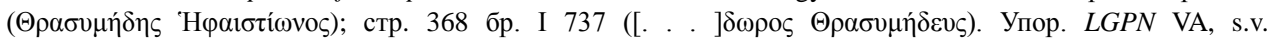
Thrasymedes (12)-(13).

${ }^{44}$ LGPN VA, s.v. Thrasymedes (3); R. Münsterberg, Die Beamtennamen auf den griechischen Münzen, repr. Hildesheim, Zürich - New York 1985, 85. За прецизније датовање новца града Ефеса на основу вредног налаза од чак 600 ефешких тетрадрахми из такозване „Пиксодарове оставе“, упор. R. H. J. Ashton, N. Hardwick, P. Kinns, K. Konuk, A. R. Meadows, The Pixodarus Hoard ( $\mathrm{CH} 9$, 421), Coin Hoards IX, Greek Hoards (edd. A. Meadows, U. Wartenberg), London 2002, 174, 188-189.

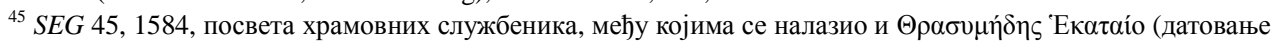

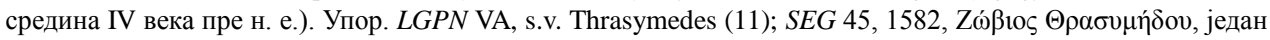
од есена, свештеника богиње Артемиде у Ефесу (хеленистички период). Упор. LGPN VA, s.v. Thrasymedes (6); I. Eph. 976, редови 5-6, 10-11, листа личних имена са патронимицима из хеленистичке епохе, међу

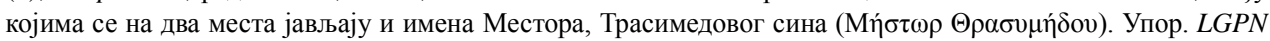
VA, s.v. Thrasymedes (8)-(9); I. Eph. 4103 II, ред 15, дугачка листа личних имена са патронимицима

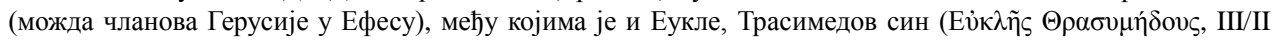
век пре н.е.). Упор. $L G P N$ VA, s.v. Thrasymedes (10).
} 


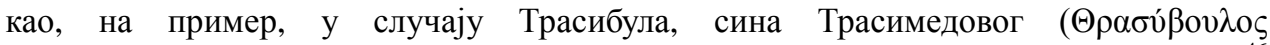
$\Theta \rho \alpha \sigma v \mu \eta ́ \delta \varepsilon о \varsigma)$, на једној листи са именима грађана Ефеса из хеленистичке епохе. ${ }^{46}$ Сличну комбинацију имена и патронимика, овог пута једног Трасимеда, сина

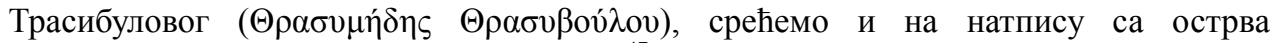
Калимноса из отприлике истог периода. ${ }^{47}$ Поред Ефеса, име Трасимед се извесно јавља и као име монетарног магистрата на новцу кованом отприлике око 300. године пре н. е. у граду Магнесији на Меандру. ${ }^{48}$

Што се тиче Хелена из Мале Азије, занимљиве потврде имена Трасимед као личног имена долазе из великог града Хераклеје Понтике. Међу носиоцима овог херојског имена посебну пажњу привлачи способни државник Трасимед из Хераклеје из епохе Митридатових ратова који је 70. године пре н. е. као посланик боравио у Риму. Он се пред Сенатом жалио на поступке римског војсковође Марка Аурелија Коте (M. Aurelius Cotta, конзул за 74. год. пре н. е.), који је, после двогодишње опсаде, заузео Хераклеју и жестоко опљачкао град, не штедећи ни храмове и уметничка блага. Посланик Трасимед је, како извештава локални историчар Мемнон из Хераклеје, дирљивим говором придобио сенаторе да донесу одлуку повољну по Хераклејане, а Кота је због својих поступака изгубио место у Сенату. По свом повратку у Хераклеју, Трасимед је такође доста учинио и на обнови девастираног града. ${ }^{49}$ Херојско име Трасимед се у Хераклеји јавља као лично име и у наредним вековима, тако да га срећемо у једној угледној породици као име оца, али и сина (потомци поменутог Трасимеда из времена позне републике?): Трасимед,

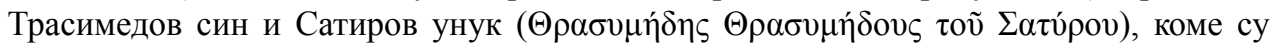
указане почасти у граду Херсонесу на полуострву Криму, колонији Хераклејана,

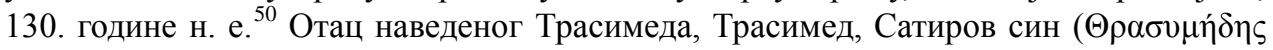
$\Sigma \alpha \tau u ́ \rho o v)$, можда је познат и на основу натписа пронађеног у Калатису на Црном мору (модерна Мангалија), граду који је такође био насеобина Хераклејана и стајао у посебним везама са својом метрополом. ${ }^{51}$ Овим Трасимедима свакако треба додати и Хераклејанина који се у 3. веку н. е. већ звао на римски начин Аурелије

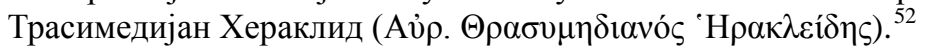

Од осталих области матичне Хеладе, име Трасимед је као лично име потврђено у Тесалији, нарочито у граду Фери, где су се у хеленистичко доба (II век пре н. е.) тако звали очеви чак два тесалска савезна стратега, што указује на то да је реч о припадницима елите не само града Фере него и читаве Тесалије. Тесал, Трасимедов син, из Фере, био је стратег Тесалаца око 140. године пре н. е. (દ̇лі

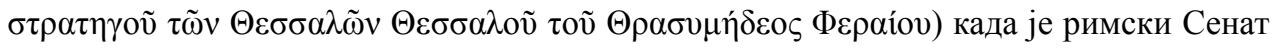

\footnotetext{
${ }^{46}$ SEG 34, 1083, редови 3-4. Упор. LGPN VA, s.v. Thrasymedes (5).

47 Tit. Cal. 85, ред 56 (датовање око 200. године пре н.е.). Упор. LGPN I, s.v. Thrasymedes (8).

${ }^{48}$ LGPN VA, s.v. Thrasymedes (14).

${ }^{49}$ FGrHist 434 F 39-40 [Memnon]; Упор. F. Canali de Rossi, Le ambascerie dal mondo greco a Roma ine età reppublicana, Roma 1997, no. 371; LGPN VA, s.v. Thrasymedes (15).

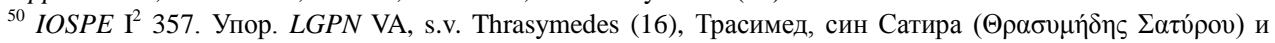

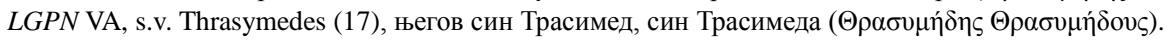

${ }^{51}$ ISM III 72, ред 18. Упор. LGPN VA, s.v. Thrasymedes (18).

${ }^{52}$ I. Heraclea 10, редови 6, 8. Упор. LGPN VA, s.v. Thrasymedianos (1) = LGPN VA, s.v. Herakleides (331).
} 
арбитрирао у спору Мелитеје и Нартакија, два тесалска града. ${ }^{53}$ Паусанија, Трасимедов син, такође из Фере, се касније (око 130. године пре н. е.) као стратег

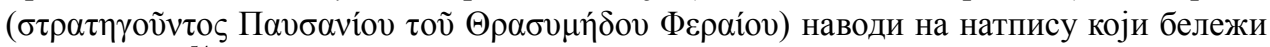
манумисије. $^{54}$

Највећи број историјских Трасимеда, међутим, потврђен је, поред Атине, на острву Родосу. Име је подједнако забележено у свим филама уједињеног острва (Линдос, Јалисос, Камирос), јавља се и као име магистрата на новцу Рођана, ${ }^{55}$ као име епонимних магистрата забележених на амфорама са Родоса, ${ }^{56}$ али и у осталим изворима, пре свега у богатом епиграфском материјалу са острва Родоса из хеленистичке епохе. ${ }^{57}$ Ако се има у виду да су херојска имена осталих Несторових синова, Антилоха и Пејсистрата, као, уосталом, и име самог Нестора, била такође популарна на Родосу, ово је можда и право место да се нешто дода о могућим разлозима зашто су поменута имена у тој мери присутна у антропонимији острва. ${ }^{58}$ Сигурно је да део одговора лежи у чињеници да је реч о именима која су имала панхеленски карактер и симболизовала оне добре особине које су биле на цени код Хелена. Оправдано је, међутим, поставити питање: зашто баш Родос и зашто су баш сва та херојска нелеидска имена и у толиком броју „била у моди“ код Рођана? Није, на основу сачуваних извора, познато да су Нестор и Нелеиди имали неку иоле значајнију улогу у митској историји овог доминантно дорског острва посвећеног богу Хелију, нити у неком од његових старих градских центара, Јалисосу, Линдосу и Камиросу, у времену пре синоикизма (политичког уједињења Родоса) 408/7. године пре н. е. Део одговора свакако треба тражити у чињеници да је Родос, нарочито у хеленистичком периоду, био богат трговачки полис који је као држава, али и поједине породице по градовима окренуте поморској трговини приватно, одржавао живе економске и политичке везе са многобројним хеленским и хеленизованим заједницама на широком простору Медитерана. ${ }^{59}$ Тим везама се делом дају објаснити и разлози за популарност херојског имена Трасимед и других нелеидских имена као личних имена на Родосу. Други део одговора стоји, можда, у вези са

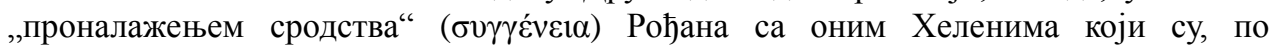
стандардима и укусима, пре свега хеленистичке епохе, могли бити сматрани Нелејевим и Несторовим потомцима и баштиницима Несторовог Пила. А то би, по свему, бар у периоду од IV века пре н. е., могли бити само Месењани. Ослобођена од спартанског ропства и организована као посебан полис од 370/69. године пре н. е., Месенија је тражила и креирала сопствену историју и митове. Ови митови су нашли

\footnotetext{
${ }^{53} I G$ IX 2, 89, редови 6-7 = Sherk, RDGE 9, редови 6-7; Упор. LGPN IIIB, s.v. Thrasymedes (2).

${ }^{54}$ Упор. LGPN IIIB, s.v. Thrasymedes (3).

${ }^{55}$ R. Münsterberg, Op. cit., 127.

${ }^{56}$ IG XII 1, 1144.

${ }^{57}$ Упор. LGPN I, s.v. Thrasymedes (10)-(24).

${ }^{58}$ Неки од основних разлога, бар када је реч о херојском имену Антилох, већ су изнети у претходном броју овог истог часописа: М. Обрадовић, Херојско име Антилох као лично име код Хелена, Истраживања 23, Нови Сад 2012, 105.

59 Упор. R. M. Berthold, Rhodes in the Hellenistic Age, Ithaca 1984, и нарочито V. Gabrielsen, The Naval Aristocracy of Hellenistic Rhodes, Aarhus 1997.
} 
одраз у епопеји о великој и славној вишевековној борби Месењана за слободу против Лакедемоњана, нарочито у вези са тзв. Другим месенским ратом, заправо устанком подигнутим против Спартанаца у VII веку пре н. е. Овај устанак је предводио месенски национални херој Аристомен, а у хеленистичком периоду га је опевао, између осталих, песник Ријан са Крита. ${ }^{60}$ Исто тако, у складу са полагањем историјског права на сву земљу западно од планине Тајгета на Пелопонезу, Месењани су својим почели сматрати и Несторов Пил, иако ни у старини није постојало слагање око тога где се славни Нелејев и Несторов град заиста налазио. ${ }^{61}$

У том откривању сопствене прошлости код Месењана накнадно је могло бити „установљено“ и њихово сродство са Рођанима, грађанима престижног полиса, а нарочито у хеленистичком периоду. Иако не постоји директна потврда овог односа

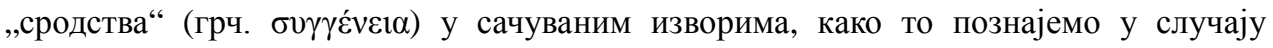
многих других заједница, како хеленских међусобно, али, исто тако, и хеленских и нехеленских, ${ }^{62}$ на „специјалне односе“ између Рођана и Месењана могла би да укаже традиција о судбини Аристомена, највећег месенског националног хероја и вође устаника против Спарте у Другом месенском рату. Јунаку Месењана није се никако „дало“ да страда у борби са Спартанцима, већ је пронашао уточиште на Родосу, где је, по традицији, и умро. ${ }^{63}$ Своју ћерку удао је за Дамагета, краља града Јалисоса на острву Родосу, од кога, по традицији, потиче једна од најславнијих породица у историји Родоса, управо она коју је у V веку пре н. е. бесмртном учинио

\footnotetext{
${ }^{60}$ Ријанова Песма о Месенији основни је извор за ескурс о месенској историји и борби против Спартанаца у Опису Хеладе периегета Паусаније (Paus. IV 14-24). Извори овог типа на добар начин сведоче како су Месењани „стварали“ своју историју. Модерна литература о настајању месенске псеудоисторије је обимна, а вреди навести нека дела која цео проблем посматрају како из угла историчара и класичних филолога исто тако и из угла археолога на основу савремених археолошких истраживања на терену: L. R. Shero, Aristomenes the Messenian, Transactions and Proceedings of the American Philological Association 69, Baltimore 1938, 500-531; L. Pearson, The Pseudo-History of Messenia and Its Authors, Historia 11, Wiesbaden 1962, 397-426; S. E. Alcock, The PseudoHistory of Messenia Unplugged, Transactions and Proceedings of the American Philological Association 129, Baltimore 1999, 333-341; N. Luraghi, Op. cit., 83-94.

${ }^{61}$ Упор. Strab. VIII 3, који детаљно расправља о три могуће локације античког Пила, од којих је само једна у „правој“ Месенији код Корифасија (преостале две су лоциране северније од Месеније у античким областима Трифилији и Елиди). У „свом“ су Пилу Месењани, као што је већ речено, с поносом гостима и путницима показивали и Несторову кућу, Несторову гробницу, као и гробницу његовог сина Трасимеда (упор. Paus. IV 36, 2). Данас, међутим, знамо да се палата владара (wa-na-ka) целе ове области у позномикенском периоду, прави Pу-го (Пилос), налазила заиста у Месенији, али на десетак километара удаљености од античког Корифасија (Пила из епохе месенске независности) на месту које се модерно назива Епано Англианос, а где су археолози открили остатке величанствене палате и богати архив са таблицама исписним Линеаром Б.

${ }^{62}$ Из превасходно политичких разлога, свакојаки историјски и псеудоисторијски разлози за сродство су

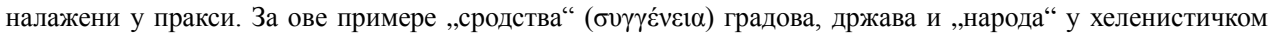
периоду данас постоји добра и обимна литература; упор. само специјалне радове на ову тему који се умножавају последњих година: O. Curty, Les parentés légendaires entre cités grecques. Catalogue raisonné des inscriptions contenant le terme suggEneia et analyse critique, Genève 1995; C. P. Jones, Kinship Diplomacy in the Ancient World, Cambridge, Mass. 1999; S. Lücke, Syngeneia: Epigraphisch-historische Studien zu einem Phänomen der antiken griechischen Diplomatie (Frankfurter althistorische Beiträge, Bd. 5), Frankfurt am Mein 2000.

${ }^{63}$ Paus. IV 24, 2-3.
} 
чувени атлета Диагора, вишеструки олимпијски победник, са својим синовима, такође победницима на панхеленским светковинама. Међутим, оно што је нарочито значајно у наведеном извештају код Паусаније је и податак (IV 24, 3) да су Рођани са своје стране подигли Аристомену величанствену гробницу и да су му указивали херојске почасти. На другом месту (IV 32, 3), Паусанија опет додаје да се Аристоменова гробница налазила у Месенији, а да су сами Месењани тврдили да она није празна, јер су кости хероја пренете са Родоса по наређењу Аполоновом. ${ }^{64}$ Ако у овој вести има уопште историјске истине, преношење Аристоменових костију се могло догодити само после 370/69. године пре н. е., настанка месенског полиса и подизања новог градског и државног центра под Итомом. То је симболично могла бити и добра прилика да се „установи сродство“ Месењана са Рођанима и учврсти све оно што повезује ове заједнице. Временски је то могло да се подудари и са све већом популарношћу имена Нестора, који је такође „постајао Месењанин“, и његових синова (Антилоха, Трасимеда, Пејсистрата) на острву Родосу. Занимљиво

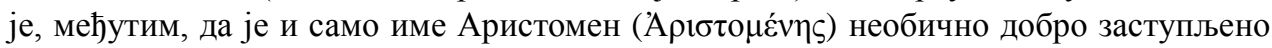
у антропонимији Родоса. Од укупно 108 Аристомена које бележи први том оксфордског Лексикона грчких личних имена (LGPN I), обухватајући, притом, сва егејска острва, Кипар и Кирену у северној Африци, чак тридесет потврда (готово $30 \%$ од укупног броја) потиче са острва Родоса. ${ }^{65}$ Популарност овог личног имена на Родосу, као, уосталом, и наведених имена Несторових синова, могла би се зато, чини се, боље разумети у светлу претпостављених историјских и псеудоисторијских веза између Рођана и Месењана. То би онда била још једна потврда изнесеног мишљења о важности које истраживање личних имена има за разумевање историјског процеса и за тражење одговора на питања која се понекад чине тешко докучивим.

За крај овог истраживања херојског имена Трасимед и његове употребе као личног имена код Хелена оставили смо један пример који, чини се, на прави начин сведочи колика је дубина проблема о коме је у раду било речи. Чак и у оним античким изворима који су стигли до нас у целости, не можемо бити апсолутно сигурни да је неко лично име у рукописима ваљано традирано. Код историчара Диодора се тако у опису догађаја из Пелопонеског рата за 426/5. годину пре н. е. наводи да се заповедник спартанске флоте код Сфактерије звао Трасимед $(\Theta \rho \alpha \sigma u \mu \eta ́ \delta \eta \varsigma) .{ }^{66}$ Да је можда, неким случајем, Диодорова Историјска библиотека једини сачувани извор који сведочи о овим догађајима и конкретно о овом спартанском науарху, не бисмо вероватно имали разлога да сумњамо да је име исправно традирано у рукописима. У том случају би се данас могло рачунати с тим да је херојско име Трасимед било заступљено и у антропонимији Спарте класичне епохе. Како је реч о угледном Лакедемоњанину, спартанском науарху, то би нас могло одвести и до одређених погрешних закључака у вези с тим и сродним

\footnotetext{
${ }^{64}$ Да досадашњи модерни покушаји идентификације ове гробнице највећег месенског хероја нису дали поузданих резултата, упор. N. Luraghi, Op. cit., 313.

${ }^{65}$ LGPN I, s.v. Aristomenes (50)-(79).

${ }^{66}$ Diod. XII 61, 3.
} 
именима у Спарти. Срећом, о истом спартанском заповеднику сведочи и Тукидид, који у IV књизи своје Историје Пелопонеског рата као науарха именује Спартанца

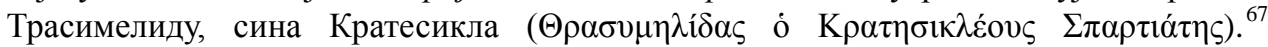
Научници с правом на овом месту дају предност Тукидиду над Диодором и усвајају да се лакедемонски заповедник звао Трасимелида, а не Трасимед. ${ }^{68}$ Међутим, у још до данас најцитиранијем приручнику за стару грчку антропонимију наводи се (штампарском грешком?) за истог науарха хибридни и у изворима незабележен

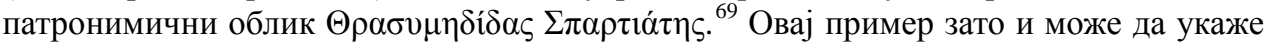
колико је важно и добро када се исправност једног имена да проверити из више извора, што, нажалост, у пракси најчешће није случај.

Списак скраћеница епиграфских и лексикографских публикација:

Agora XV = B. D. Meritt, J. S. Traill, The Athenian Agora, XV. The Athenian Councillors, Princeton 1974.

Agora XVII = D. W. Bradeen, The Athenian Agora, XVII. Inscriptions: The Funerary Monuments, Princeton 1974.

Agora XIX = G. V. Lalonde, M. K. Langdon, M. B. Walbank, The Athenian Agora, XIX. Inscriptions: Horoi, Poletai Records, Leases of Public Lands, Princeton 1991.

Chantraine, $D E L G$ = P. Chantraine, Dictionnaire étymologique de la langue Grecque. Histoire des mots, I-IV, Paris 1968-1980.

FGrHist = F. Jacoby, Die Fragmente der griechischen Historiker, Leipzig-Leiden 1923-1957. Erster Teil: Genealogie und Mythographie, Leipzig 1923, Leiden $1957^{2}$. Zweiter Teil: Zeitgeschichte (1926-1930). Dritter Teil: Geschichte von Städten und Völkern (19401954).

I. Eph. = H. Wankel, R. Merkelbach et alii, Die Inschriften von Ephesos, I-VII (Inschriften griechischer Städte aus Kleinasien Band 11-17), Bonn 1979-1981.

$I G$ = Inscriptiones Graecae:

IG $\mathrm{I}^{3}=$ Inscriptiones Graecae I: Inscriptiones Atticae Euclidis anno anterior, Berlin 1981-1994.

Fasc. 1, ed. D. Lewis, Decreta et Tabulae Magistratuum (nn. 1-500); fasc. 2, ed. D. Lewis, L. Jeffery, Dedicationes. Catalogi. Termini. Tituli Sepulcrales. Varia. Tituli Attici Extra Atticam Reperti. Addenda (nn. 501-1517).

IG $\mathrm{II}^{2}=$ Inscriptiones Atticae Euclidis anno posteriores, I-III, ed. J. Kirchner, Berlin 1913-1940.

$I G \mathrm{IV}^{2} 1$ = Inscriptiones Graecae IV: Inscriptiones Argolidis. Fasc. 1, Inscriptiones Epidauri, ed. F. Hiller von Gaertringen. Berlin 1929.

IG IX 2 = Inscriptiones Graecae IX 2: Inscriptiones Thessaliae, ed. O. Kern, Berlin 1908.

IG XII 1 = Inscriptiones Graecae XII. Inscriptiones insularum maris Aegaei praeter Delum, fasc. 1. Inscriptiones Rhodi, Chalces, Carpathi cum Saro, Casi, ed. F. Hiller von Gaertringen, Berlin 1895.

IG XII 5 = Inscriptiones Graecae XII,5. Inscriptiones Cycladum, ed. F. Hiller von Gaertringen, I-II,

\footnotetext{
${ }^{67}$ Thuc. IV 11, 2.

${ }^{68}$ Упор. Р. Poralla, Prosopographie der Lakedaimonier bis auf Zeit Alexanders des Großen, Breslau 1913, 66 s.v. Thrasymelidas; LGPN IIIA, s.v. Thrasymelidas (1).

${ }^{69}$ F. Bechtel, Op. cit., 212.
} 
Berlin 1903-1909.

I. Heraclea $=$ L. Jonnes, Inscriptions of Heraclea Pontica (Inschriften griechischer Städte aus Kleinasien, Band 47), Bonn 1994.

IOSPE $\mathrm{I}^{2}=\mathrm{V}$. Latyshev, Inscriptiones antiquae orae septentrionalis Ponti Euxini graecae et latinae

$I^{2}$ : Inscriptiones Tyrae, Olbiae, Chersonesi Tauricae, Petropolis 1916.

ISM III = A. Avram, Inscriptiones Scythiae Minoris graecae et latinae III: Callatis et territorium, Bucharest 1999.

$L G P N=$ A Lexicon of Greek Personal Names:

$L G P N$ I = P. M. Fraser, E. Matthews (edd.), A Lexicon of Greek Personal Names I: The Aegean Islands, Cyprus and Cyrenaica, Oxford 1987.

LGPN II = M. G. Osborne, S. G. Burne (edd.), A Lexicon of Greek Personal Names II: Attica, Oxford 1994.

LGPN III A = P. M. Fraser, E. Matthews (edd.), A Lexicon of Greek Personal Names IIIA: The Peloponnese, Western Greece, Sicily and Magna Graecia, Oxford 1997.

LGPN III B = P. M. Fraser, E. Matthews (edd.), A Lexicon of Greek Personal Names IIIB: Central Greece: From the Megarid to Thessaly, Oxford 2000.

LGPN IV = P. M. Fraser, E. Matthews (edd.), A Lexicon of Greek Personal Names IV: Macedonia, Thrace, Northern Regions of the Black Sea, Oxford 2005.

$L G P N$ V A = Th. Corsten, R. W. V. Catling, M. Ricl (edd.), A Lexicon of Greek Personal Names V A: Coastal Asia Minor: Pontos to Ionia, Oxford 2010.

P. Oxy. IV = The Oxyrhynchus Papyri, Part IV (edd. B. P. Grenfell, A. S. Hunt), Oxford 1904.

$R E=$ Pauly-Wissowa (edd.), Real-Encyclopädie der classischen Altertumswissenschaft, Stuttgart 1893-1980.

Reinmuth, Ephebic Inscr. = O. W. Reinmuth, The Ephebic Inscriptions of the Fourth Century B.C., Leiden 1971.

Roscher = W. H. Roscher (ed.), Ausführliches Lexikon der griechischen und römischen Mythologie, Leipzig 1884-1937.

SEG = Supplementum Epigraphicum Graecum, Leiden-Amsterdam 1923- .

Sherk, $R D G E=$ R. K. Sherk, Roman Documents from the Greek East. Senatus Consulta and Epistulae to the Age of Augustus, Baltimore 1969.

Tit. Cal. = M. Segre, Tituli Calymnii, Annuario della Scuola Archeologica di Atene e delle Missione Italiane in Oriente XXII-XXIII (Nuova Serie VI - VII), 1944-1945.

\section{Литература:}

Alcock, S. E., Tomb Cult and Post-Classical Polis, American Journal of Archaeology 95, Boston 1991, 447-467.

Alcock, S. E., The Pseudo-History of Messenia Unplugged, Transactions and Proceedings of the American Philological Association 129, Baltimore 1999, 333-341.

Ashton, R. H. J. - Hardwick, N. - Kinns, P. - Konuk, K. - Meadows, A. R., The Pixodarus Hoard ( $\mathrm{CH}$ 9, 421), Coin Hoards IX, Greek Hoards (edd. A. Meadows, U. Wartenberg), London 2002, 159-243.

Bechtel, F., Die historischen Personennamen des Griechischen bis zur Keiserzeit, Halle 1917.

Berthold, R. M., Rhodes in the Hellenistic Age, Ithaca 1984.

Burford, A., The Greek Temple Builders at Epidauros, Liverpool 1969.

Canali de Rossi, F., Le ambascerie dal mondo greco a Roma ine età reppublicana, Roma 1997.

Curty, O., Les parentés légendaires entre cités grecques. Catalogue raisonné des inscriptions contenant le terme suggEneia et analyse critique, Genève 1995. 
Davies, J. K., Athenian Propertied Families 600-300 B.C., Oxford 1971.

Eliot, C. W., Where did the Alkmaionidai Live?, Historia 16, Wiesbaden 1967, 279-286.

Etienne, R., Ténos II. Ténos et les Cyclades du milieu du IV siècle av. J.-C. au III ${ }^{e}$ siècle ap. J.-C., Paris 1990.

Fick, A., Die griechischen Personennamen nach ihrer Bildung erklärt und systematisch geordnet (bearbeitet von F. Bechtel und A. Fick), Göttingen 1894².

Gabrielsen, V., The Naval Aristocracy of Hellenistic Rhodes, Aarhus 1997.

Haubold, J., Homer's People: Epic Poetry and Social Formation, Cambridge 2000.

Janko, R., The Iliad. A Commentary, Vol. IV, Books 13-16, Cambridge 1994.

Jones, C. P., Kinship Diplomacy in the Ancient World, Cambridge, Mass. 1999.

Kamptz, H. von, Homerische Personennamen: sprachwissenschaftliche und historische Klassifikation, Göttingen 1982.

Lapatin, K. D. S., Chryselephantine Statuary in the Ancient Mediterranean World, Oxford 2001.

Lücke, S., Syngeneia: Epigraphisch-historische Studien zu einem Phänomen der antiken griechischen Diplomatie (Frankfurter althistorische Beiträge, Bd. 5), Frankfurt am Mein 2000.

Luraghi, N., The Ancient Messenians: Constructions of Ethnicity and Memory, Cambridge 2008.

Meritt, B. D., Inscriptions of Colophon, American Journal of Philology 56, Baltimore 1935, 358397.

Münsterberg, R., Die Beamtennamen auf den griechischen Münzen, repr. Hildesheim, Zürich - New York 1985.

Parker, R., Athenian Religion: A History, Oxford 1996.

Pearson, L., The Pseudo-History of Messenia and Its Authors, Historia 11, Wiesbaden 1962, 397-426.

Poralla, P., Prosopographie der Lakedaimonier bis auf Zeit Alexanders des Großen, Breslau 1913.

Shero, L. R., Aristomenes the Messenian, Transactions and Proceedings of the American Philological Association 69, Baltimore 1938, 500-531.

Schweigert, E., Greek Inscriptions (1-13), Hesperia 8, Athens 1939, 1-47.

Stewart, A., Greek Sculpture: An Exploration, New Haven and London 1990.

Thomas, R., Oral Tradition and Written Record in Classical Athens, Cambridge 1989.

Toepffer, J., Attische Genealogie, Berlin 1889.

Ventris M. - Chadwick, J., Documents in Mycenaean Greek, Cambridge 1956.

Wade-Gery, H. T., Eupatridai, Archons, and Areopagus I-II, Classical Quarterly 25, London 1931, 1-11, 77-89.

West, M. L., The East Face of Helicon. West Asiatic Elements in Greek Poetry and Myth, Oxford 1997. 


\title{
STUDIES IN NELEID ANTHROPONYMY II: THE HEROIC NAME THRASIMEDES AS GIVEN NAME AMONG THE HELLENES
}

\author{
Summary
}

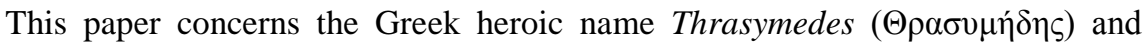
examines its distribution as a personal name in the ancient Greek world, from the Archaic to the Roman Imperial period. Possible reasons for choosing this heroic name for mortals have been discussed based on ample onomastic material drawn from various parts of the Greek world. Assigned to the category of heroic names, the name Thrasymedes was quite widely found in several areas of the ancient Greek world, mainly in the Classical and Hellenistic periods. It could sound to the Greeks as a good Panhellenic name, but its popularity can also be explained with possible Neleid associations. The hero Thrasymedes was a son of Nestor and accompanied his father to the Trojan War. He was also among the warriors inside the Wooden Horse in later tradition, and returned successfully to Pylos, where he welcomed Telemachos in the Odyssey. After the death of his father, Thrasymedes ruled the kingdom of Pylos, but his descendants, along with the other Neleids, were forced to leave the Peloponnese by the invading Dorians, and settled in Attica. Claiming descent from heroes of Greek myth had been a traditional way for Greek aristocrats to articulate their social superiority. Thus, for example, a grandson of Thrasymedes, Alkmaion, the son of Syllos, became the progenitor of the noble Athenian family of the Alkmaionidai.

The name Thrasymedes as a good Neleid name could be acceptable to the Ionians especially, hence its popularity in Attica, Ionia, and some of the Aegean Islands. Although the name seems to reflect the aristocratic attitudes of the upper classes, its popularity in Athens of the Classical period (over twenty attestations), can be explained primarily with its basic meaning and expectations from the bearer of the name. Like other names derived from the adjective $\vartheta \rho \alpha \sigma u ́ \varsigma$ ("audacious, courageous, bold, resolute", but see an equally characteristic second component $-\mu \dot{\eta} \delta \eta \varsigma$ ) the heroic name Thrasymedes refers to the characteristics a successful warrior and statesman should have. The names of $\Theta \rho \alpha \sigma v$ - type, in general, provide important contribution to our understanding of Greek naming practices. These names well correspond to the restless spirit of the Classical period Athenians that led Athens to create an empire, because they reflect those characteristics of the citizens which were much respected in the democracy - decisive and energetic actions and readiness to sacrifice private considerations for the sake of public good.

Leaving aside Athens, there are frequent attestations of the name Thrasymedes on the islands of the Aegean Sea, especially on Rhodes, while they are rare in the Peloponnese and Western Greece. It is not a surprise that the heroic name Thrasymedes is mostly found in anthroponymy of the island of Rhodes, because it is exceptionally richly documented and the unified state of Rhodes, as a large economic and trading centre of the Hellenistic world, maintained intensive economic and political relations with many Greek 
cities in a wide area of the Mediterranean basin. The reasons for the popularity of the heroic name Thrasymedes and other Neleid names on the island of Rhodes might also be

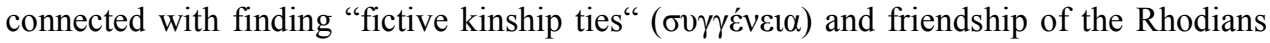
with those Greeks who could have been considered, by standards of the Hellenistic period, Nestor's descendents. From the fourth century B.C. those were, first of all, the Messenians. Nestor and his sons were so prominent in the Homeric epics and since the fifth or fourth century at the latest their kingdom was widely identified with Messenia and Pylos with Koryphasion. These supposed historical and pseudo-historical connections between the Rhodians and the Messenians could explain frequent attestations of the name Thrasymedes, as well as of the other Neleid names (Nestor, Antilochos, Peisistratos) as personal names on the island of Rhodes, especially in the Hellenistic period.

Keywords: Thrasymedes, Greek anthroponymy, myth, Greek epic tradition, history, politics, cultural values. 